\title{
OPTIMIZATION OF CONDITIONS FOR RECOMBINANT DNA INJECTION INTO SPERMATOGENIC CELLS OF THE CHICKEN in vivo
}

\author{
N.A. Volkova ${ }^{1}$, L.A. Volkova ${ }^{1}$, I.K. Fomin ${ }^{1}$, N.A. Zinovieva ${ }^{1}$, N.S. Lotsmanova ${ }^{2}$ \\ ${ }^{1}$ All-Russia Research and Development Institute for Livestock Husbandry, RAAS, Dubrovitsy settlement 142132, Moscow province, Russia \\ e-mail:natavolkova@inbox.ru \\ ${ }^{2}$ Base Medical College № 15 of Moscow Healthcare Department, Moscow 109263, Russia
}

Received October 15, 2012

Sum mary

\begin{abstract}
The factors affecting the efficiency of the transfer of recombinant DNA into seminiferous epithelium of the chicken in vivo using retroviral vectors are studied. The maximum efficiency of the transformation of spermatogenic cells in chicken is demonstrated when virus was used as a source of genetic structure (pLgfpSN gene construct which contains the reporter gene of green fluorescent protein GFP based on the recombinant retroviral vector). The possibility of transmission of the transgene to offspring with the efficiency of transgenesis $4.2 \%$ is shown.
\end{abstract}

Keywords: transgenesis, retrovirus vectors, spermatogonia cells, chicken.

Using male germ cells as target cells for DNA transfer is considered as one of the promising methods for producing transgenic animals (1-5). The development of this technique is quite urgent in bioengineering of poultry, because peculiarities of bird's reproduction doesn't allow the directed gene transfer commonly applied in farm animals by microinjection of DNA into pronucleus of zygotes (6). The role of male germ cells as vectors for the transfer of recombinant genes is primarily associated with their natural ability to absorb foreign DNA (fDNK) and bring it into ovule during fertilization (7). Once being integrated into the genome, fDNA can be stably inherited in the line of following generations. In this case, manipulations on adult animals significantly reduce financial and time costs on obtaining transgenic offspring.

Today, genetic transformation of male germ cells can be performed using a number of various techniques and approaches lipofection, electroporation, viral transduction, etc., but the systems for effective transfer of recombinant DNA in target cell haven't been yet developed. At the same time, establishing such systems would open easy and convenient way to produce transgenic animals, since artificial insemination has been successfully used in agricultural practice for a long time.

A promising method for genetic modification of germ cells is using retroviral vectors that cause target transformation in a specific type of cells at early stages of their differentiation, which provides effective introduction of desired genes and their subsequent expression.

In this regard, the presented work was aimed at optimization of conditions for the transfer of foreign DNA into chicken male germ cells in vivo using retroviral vectors.

Technique. Transformation of male germ cells in spermatogenic epithelium of roosters was performed using the gene construct pLgfpSN containing the reporter gene GFP (green fluorescent protein). The construct was designed based on retrovirus vector pLXSN (8) and introduced by transfection into packaging cells the line GP + env-AM12 ensuring in trans all the functions necessary for virus replication (9). To determine the virus titer (CFU/ml) of viral preparation, the supernatant collected from packaging cells (line GP+env-AM12) was centrifuged for $10 \mathrm{~min}$ at $3000 \mathrm{~g}$ to remove cells and debris. The infection was performed immediately after collecting the virus. Recipient cells $293 \mathrm{~T}$ were plated in Petri dishes at a density of $3 \frac{1}{1} 210^{5}(\mathrm{~d}=60 \mathrm{~mm}) 24 \mathrm{hours}$ prior to infestation. On the second day, the medium was replaced by $1 \mathrm{ml}$ of fresh medium containing polybrene $(8 \mathrm{ug} / \mathrm{l})$ and aliquots of the tested virus. Incubation was performed for $6 \mathrm{~h}$, then the medium was replaced with the fresh one. After $48-72 \mathrm{~h}$ of incubation, the cells were detached with trypsin, resuspended in PBS and the fluorescence of GFP was measured on flow cytometer FACSCanto ("BD", USA) with a set of filters $480-490 \mathrm{~nm}$ (excitation) and $510 \mathrm{~nm}$ (emission).

Introduction of the gene construct into the parenchyma of testes in vivo was performed by multiple injections (5-8 injections per testis). The tested sources of the construct were the suspension of packaging cells and the viral preparation - a culture medium of packaging cells containing the recombinant retrovirus (10). The viral preparation $\left(10^{5} \mathrm{CFU} / \mathrm{ml}\right)$ was introduced with the addition of polybrene $(8 \mathrm{ug} / \mathrm{ml})$. The dose of packaging cells per testis ranged from 0,5 to 2,0 millions.

The analysis of transgene integration and expression was done by PCR and immunohistochemical method (11). During immunohistochemical examination, it was studied at least 20 sections (4-5 microns thick) of the testes with an interval of 50 um. The material for histological examination was collected at slaughter of the experimental chickens; the testes were fixed with Bouin solution. Histological sections were prepared using a standard procedure (12). It was investigated at least 30 seminiferous tubules in each individual (only the round shaped ones). Histologic specimens were investigated using Image Scope software ("Systems for Microscopy and Analysis", Moscow).

To assess the efficiency of inheritance of the transgene in offspring, the viral preparation was used as a source of the gene construct for genetic modification of roosters' $(n=6)$ testes in vivo. The gene construct was introduced into the testes of 2,5-monthold individuals. The effectiveness of gene transfer to offspring was determined by examination of embryos - descendants of the experimental males (at least 100 embryos from each rooster). Recombinant DNA in chicken embryos was revealed by PCR.

Statistical calculation of results was conducted in Microsoft Excel.

Results. Introduction of the gene construct pLgfpSN into the testes of chickens was performed according to the schemes presented below (Table 1).

Integration and expression of the reporter gene GFP in male germ cells were identified in both cases of using the virus preparation and the suspension of packaging cells (Fig.). The number of transformed male germ cells per seminiferous tubule varied from 1 to 26, regardless of a source of the gene construct. 
1. The schemes used for introduction of the gene construct pLgfpSN into testes of four groups of roosters in vivo

\begin{tabular}{|c|c|c|c|c|}
\hline \multirow{2}{*}{ Parameter } & \multicolumn{4}{|c|}{ Groups } \\
\hline & I & II & III & IV \\
\hline Suspension volume per testis, $\mathrm{ml}$ & 1 & 1 & 1 & 1 \\
\hline Concentration of viral preparation, $\mathrm{CFU} / \mathrm{ml}$ & $1 \times 10^{5}$ & - & - & - \\
\hline Number of packaging cells per testis, million & - & 0,5 & 1,0 & 2,0 \\
\hline Age of individuals, weeks & 3 & 3 & 3 & 3 \\
\hline Number of individuals, $n$ & 3 & 3 & 3 & 3 \\
\hline
\end{tabular}
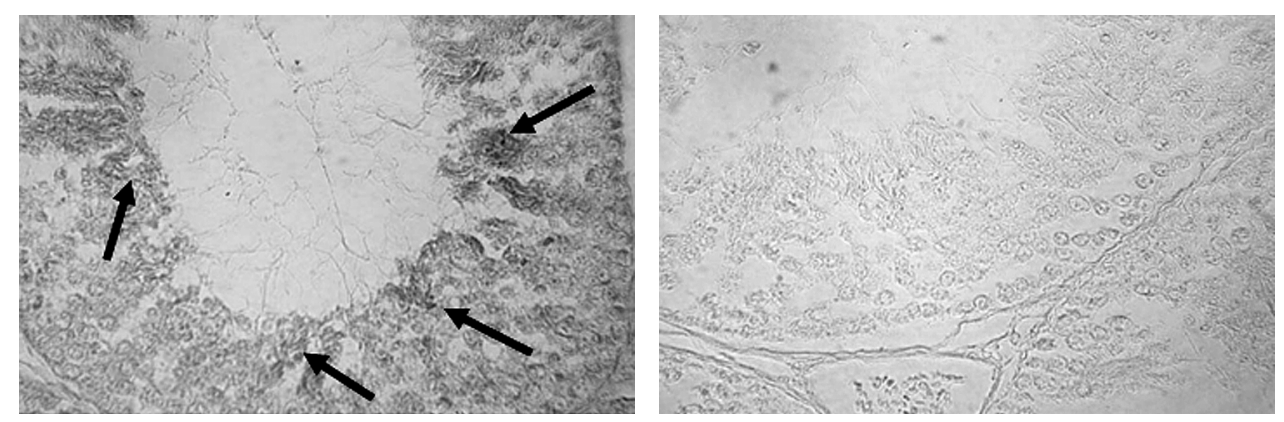

Immunohistochemical staining reveals in a specimen of chicken testis the expression of reporter gene GFP introduced by the gene construct pLgfpSN derived using recombinant retrovirus vector (left — experiment, right - control). Arrows point to transformed male germ cells in seminiferous tubules. Chromogene - aminoethyl carbazole, magnification $\times 400$.

2. Efficiency of genetic transformation of seminiferous tubules and male germ cells in spermatogenic epithelium of chicken testes in vivo depending on the scheme used for introduction of the gene construct pLgfpSN

\begin{tabular}{|c|c|c|c|c|}
\hline \multirow{2}{*}{ Parameter } & \multicolumn{4}{|c|}{ Group, $n=3$} \\
\hline & I & II & III & IV \\
\hline Concentration of viral preparation, $\mathrm{CFU} / \mathrm{ml}$ & $4,2 \times 10^{5}$ & - & - & - \\
\hline Number of packaging cells per testis, million & - & 0,5 & 1,0 & 2,0 \\
\hline Number of examined sections per individual, $n$ & 20 & 20 & 20 & 20 \\
\hline Proportion of sections with transformed seminiferous tubules, \% & 85 & 85 & 50 & 35 \\
\hline \multicolumn{5}{|l|}{ Proportion of transformed seminiferous tubules per section, $\%$ : } \\
\hline minimum & 1,7 & 5,9 & 1,7 & 2,5 \\
\hline maximum & 31,0 & 47,1 & 31,3 & 13,2 \\
\hline mean over the group & $15,7 \pm 2,10$ & $18,1 \pm 2,60$ & $10,7 \pm 2,20$ & $5,8 \pm 0,90$ \\
\hline Total efficiency of transformation of seminiferous tubules, \% & $13,3 \pm 2,30$ & $9,1 \pm 2,70$ & $8,6 \pm 2,20$ & $2,3 \pm 0,90$ \\
\hline \multicolumn{5}{|l|}{ Proportion of transformed male germ cells in seminiferous tubules, \%: } \\
\hline minimum & 1,8 & 1,3 & 0,1 & 0,7 \\
\hline maximum & 32,2 & 47,2 & 21,1 & 11,1 \\
\hline mean over the group & $1,5 \pm 0,30$ & $1,0 \pm 0,30$ & $0,6 \pm 0,20$ & $0,3 \pm 0,05$ \\
\hline Total efficiency of transformation of male germ cells in seminiferous tubules, $\%$ & $1,3 \pm 0,30$ & $0,5 \pm 0,20$ & $0,3 \pm 0,20$ & $0,1 \pm 0,04$ \\
\hline $\begin{array}{l}\text { Note } \text {. Total efficiency of transformation of seminiferous tubules - percenta } \\
\text { tubules to total number of examined seminiferous tubules. Total efficiency of tra } \\
\text { transformed germ cells to total number of investigated male germ cells. }\end{array}$ & $\begin{array}{l}\text { ratio of tl } \\
\text { sfformation }\end{array}$ & $\begin{array}{l}\text { e number o } \\
\text { f male gern }\end{array}$ & $\begin{array}{l}\text { transformed } \\
\text { cells - perc }\end{array}$ & $\begin{array}{l}\text { eminiferous } \\
\text { tage ratio o }\end{array}$ \\
\hline
\end{tabular}

In the variant of the viral preparation as a source of the gene construct, seminiferous tubules with transformed male germ cells were detected only in 51 of the 60 studied sections, which amounted to $15,7 \pm 2,1 \%$ tubules per section (Table 2). The proportion of transformed cells per section varied from 1,8 to $32,2 \%$ and averaged $1,5 \pm 0,3 \%$ over the group. At the same time, total efficiency of transformation of seminiferous tubules and spermatogenic epithelium of testes (percentage ratio of the number of transformed seminiferous tubules and male germ cells to their total number in all investigated sections) was, respectively, $13,3 \pm 2,3$ and $1,3 \pm 03 \%$.

A series of experiments was performed in order to improve the efficiency of transgenesis by optimizing the dose of the gene construct injected into chicken testes in vivo. In these experiments, a source of the gene construct was suspension of packaging cells (0,5-2,0 million cells per dose). It was supposed that increasing the dose of administered packaging cells will improve the efficiency of transgenesis in male germ cells. However, increased doses of packaging cells caused the inverse trend. Along with it, using the suspension of packaging cells reduced the efficiency of transfer of the recombinant DNA into seminiferous tubules and male germ cells compared with the variant of viral preparation. Thus, after the injection of 0,5 million packaging cells per testis, the estimated efficiency of transformation of seminiferous tubules was $9,1 \pm 2,7 \%$, male germ cells - $0,5 \pm 0,2 \%$, i.e. $1,5-2,6$ times lower than those in the variant of viral preparation. Introducing the higher dose of 2,0 million packaging cells per testis provided more pronounced differences in the studied parameters: the efficiency of transformation of seminiferous tubules did not exceed $2,3 \pm 0,9 \%$, male germ cells - 0,1 $\pm 0,04 \%$. Probably, the low rate of transformation of male germ cells in chicken testes observed at high doses of administered packaging cells was associated with immune response against the introduced foreign cells.

The possibility of gene transfer using the viral preparation as a source pLgfpSN gene construct injected in chicken testes in vivo was confirmed by examining the offspring of experimental males. The number of transgenic embryos in offspring of different experimental roosters ranged from 1 to 7 and averaged 4,2\%. From two roosters with the maximum efficiency of transformation of male germ cells it was obtained 30 chickens, two of which were found to be carriers of the transgene. These facts indicate the possibility of using the gene constructs based on recombinant retroviruses for genetic transformation of chicken male germ cells in vivo; the proposed approach is fast, inexpensive, and it can be considered as an effective alternative to other known methods of obtaining transgenic poultry.

Thus, the authors have optimized the conditions of introducing gene constructs into chicken testes in vivo. The maximum efficiency of transformation of male germ cells was observed in the variant of viral preparation used as a source of gene construct. The introduced gene construct pLgfpSN was identified in two chickens among the offspring of experimental roosters with the highest 
frequency of germ cell transformation, which shows the prospects for genetic transformation of poultry using gene constructs based on recombinant retroviruses.

\section{REFERENCES}

1. Brinster R.L. and Nagano M., Spermatogonial Stem Cell Transplantation, Cryopreservation and Culture, Semin. Cell. Dev. Biol., 1998, vol. 9, no. 4, pp. 401-409.

2. Savchenkova I.P., Korzhikova S.V., Kostereva N.V., and Ernst L.K., Cultivation and Transplantation of Boars' Spermatogonia the A-Type, Ontogenez, 2006, vol. 37, no. 4, pp. 292-300.

3. Korzhikova S.V., Isolation, Characterization and Transplantation of Boars' Spermatogonia the A-Type, Extended Abstract of Cand. Sci. Dissertation, Dubrovitsy, 2002 .

4. Novgorodova I.P., Mormyshev A.N., Volkova N.A., Zinovieva N.A., and Ernst L.K., In Vivo Genetic Transformation of Rabbit Spermatogonia Cells, Biotechnology in Russia, 2008, vol. 1, pp. 35-41.

5. Volkova N.A., Zinovyeva N.A., Volkova L.A., Lotsmanova N.S., and Ernst L.K., Study of Factors Affected the Efficiency of Gene Transfer into the Male Germ Cells of Agricultural Animals, S.-kh. biol., 2010, vol. 6, pp. 16-19.

6. Ivarie R., Avian Transgenesis: Progress towards the Promise, Trends Biotechnol., 2003, vol. 21, pp. 14-19.

7. Spadafora C., Sperm Cells and Foreign DNA: a Controversial Relation, Bioassays, 1998, vol. 20, pp. 955-964.

8. Miller A.D. and Rosman G.J., Improved Retroviral Vectors for Gene Transfer and Expression, Biotechniques, 1989, vol. 7, pp. 980-990.

9. Markowitz D., Goff S., and Bank A., Construction and Use of a Safe and Efficient Amphotropic Packaging Cell Line, Virology, 1988 , vol. 167, pp. 400-406.

10. Novoye v klonirovanii DNK. Metody (DNA Cloning. Methods), Glover D., Ed., Moscow, 1989.

11. Mikroskopicheskaya tekhnika: Rukovodstvo (Microscopy Technique: Guidelines), Sarkizov D.S. and Petrov Yu.P., Eds., Moscow, 1996.

12. Romeis B., Mikroskopicheskaya tekhnika (Microscopy Technique), Moscow, 1953. 